\title{
Features of cardiac remodeling depending on the mode of training session
}

\author{
S. M. Malakhova ${ }^{(B, D, F}$, V. V. Syvolap ${ }^{A, C, E}$, M. S. Potapenko ${ }^{\mathrm{D}, \mathrm{E}}$
}

Zaporizhzhia State Medical University, Ukraine

A - research concept and design; B - collection and/or assembly of data; C - data analysis and interpretation; D - writing the article;

$\mathrm{E}$ - critical revision of the article; $\mathrm{F}$ - final approval of the article

Different types of physiological adaptation of the heart in athletes are formed depending on the specifics of sports activities. In cyclic, mostly aerobic training athletes (long-distance running, skiing, swimming), left ventricular (LV) dilation with a proportional increase in its wall thickness are mainly developed. Athletes participating in sports with mostly static or isometric component (weightlifters, wrestlers, throwers) develop concentric hypertrophy with increased LV wall thickness without changes in the cavity size. However, changes in the heart geometry in athletes are not limited to eccentric or concentric LV hypertrophy.

The aim of this work was to study the features of athletes' heart remodeling depending on the mode of training session (endurance, speed, strength).

Material and methods. After the signing of the informed consent, 104 athletes (84 men and 20 women) were involved in the study: 63 - athletes who mainly trained endurance performance, 31 - strength athletes, 10 - speed athletes. The mean age of the athletes was $21.75 \pm 3.32$ years. Among them, there were Masters of Sports of International Class (MSIC) -2 athletes, Masters of Sports (MS) - 25, Candidates Master of Sports (CMS) - 48, First-Class athletes - 29. All the athletes underwent M - and B-mode echocardiographic examination, Doppler interrogation of transvalvular flows and tissue Doppler imaging.

Results. In the endurance athletes, unlike the strength athletes, the diameter of the left atrium $(P=0.019)$ and the right ventricle $(P=0.004)$ as well as left ventricular myocardial mass index $(L V M M I)(P=0.004)$ prevailed, all other indicators showed no differences. In the endurance athletes, unlike the speed athletes, interventricular septal thickness (IVST) $(P=0.015), \operatorname{LVMMI}(P=0.003)$, left ventricle ejection fraction (LVEF) $(P=0.035)$ and pressure gradient in the aorta $(P=0.024)$ prevailed. In the strength athletes, unlike the speed athletes, left ventricular end-diastolic diameter was $10.8 \%(P=0.004)$ larger. The largest left atrial diameter was detected in the endurance athletes, the smallest one - in the strength athletes $(P=0.019)$.

Conclusions. Despite long-term exercise, normal left ventricular geometry remained in $90 \%(9 / 10)$ of the speed athletes, in $74.2 \%(23 / 31)$ of the strength athletes, in $46.0 \%(29 / 63)$ of the endurance athletes ( $P=0.012)$. Left ventricular hypertrophy most commonly occurred in the endurance athletes, unlike the strength athletes $(47.6 \%$ vs. $25.8 \%, P=0.044)$. Eccentric hypertrophy significantly prevailed over concentric type in the structure of hypertrophy in both the endurance athletes $(34.9 \%$ vs. $12.7 \%, P=0.045$, respectively) and strength athletes (22.6 \% vs. $3.2 \%, P=0.023$, respectively).

\section{Особливості кардіального ремоделювання залежно від спрямованості тренувального процесу}

\section{С. М. Малахова, В. В. Сиволап, М. С. Потапенко}

Різні види фізіологічної адаптації серця в атлетів формуються залежно від специфріки спортивної діяльності. У спортсменів, які тренуються в циклічних, насамперед аеробних видах спорту (біг на довгі дистанції, лижний спорт, плавання), здебільшого розвивається дилятація порожнини лівого шлуночка (ЛШ) із пропорційним збільшенням товщини його стінок.

Якщо у тренуванні переважають статичні або ізометричні навантаження (важкоатлети, єдиноборці, метальники), у спортсменів розвивається концентрична гіпертрофрія зі збільшенням товщини стінки ЛШ без зміни розміру його порожнини. Але зміни геометрії серця в атлетів не обмежуються тільки ексцентричною та концентричною гіпертрофією ЛШ.

Мета роботи - вивчення особливостей ремоделювання серця спортсменів залежно від спрямованості тренувального процесу (витривалість, швидкість, сила).

Матеріали та методи. Після підписання інформованої згоди в дослідження залучили 104 спортсмени (84 чоловіки та 20 жінок): 63 - атлети, які розвивали здебільшого якість витривалості; 31 - якість сили, 10 осіб - якість швидкості. Середній вік обстежених $-21,75 \pm 3,32$ року. Серед них майстрів спорту міжнародного класу (МСМК) -2 спортсмени, майстрів спорту (MC) -25 , кандидатів у майстри спорту - 48, спортсменів 1 розряду - 29 осіб.

Усім спортсменам виконали ехокардіографічне дослідження в М, В режимах, доплерографічне оцінювання трансклапанних потоків, тканинний доплер.

Результати. У спортсменів, які розвивали якість витривалості, на відміну від спортсменів, котрі розвивали якість сили, переважали розміри лівого передсердя ( $p=0,019)$, правого шлуночка $(p=0,004)$, ІІММШ $(p=0,004)$, за рештою показників різниця відсутня. У спортсменів, котрі розвивали якість витривалості, на відміну від спортсменів, які розвивали якість швидкості, переважала товщина МШП ( $=0,015)$, ІММЛШ ( $p=0,003)$, ФВ ЛШ ( $=0,035)$, градієнт тиску $(p=0,024)$ в аорті. У спортсменів, які розвивали якість сили, на відміну від атлетів, котрі розвивали якість швидкості, на 10,8 \% $(p=0,004)$ переважав кінцевий діастолічний розмір ЛШ. Вірогідно найбільші розміри передсердя зареєстрували у спортсменів, які насамперед розвивали якість витривалості, найменші - у спортсменів, які розвивали якість сили $(p=0,019)$.
Key words: cardiac remodeling physical education and training.

Zaporozhye medical journal 2020; 22 (5), 643-651

*E-mail: malakhova sn@ukr.net

Ключові слова: кардіальне ремоделювання, фізичне виховання та навчання.

Запорізький медичний журнал. 2020. T. 22, № 5(122). C. $643-651$ 
Висновки. Незважаючи на тривалі фізичні навантаження, нормальна геометрія ЛШ залишилася в 90 \% (9/10) атлетів, які удосконалювали якість швидкості, у 74,2 \% (23/31) спортсменів, котрі розвивали передусім якість сили, у 46,0 \% (29/63) атлетів, які удосконалювали якість витривалості ( $p=0,012)$. Гіпертрофрія ЛШ частіше виникала $(47,6 \%$ проти $25,8 \%, p=0,044)$ у спортсменів, які розвивали переважно якість витривалості, на відміну від спортсменів, які удосконалювали якість сили. У структурі гіпертрофії у спортсменів, котрі розвивали якості витривалості й сили, вірогідно переважала ексцентрична гіпертрофрія над концентричною: витривалість (ЕГЛШ 34,9 \% проти КГЛШ 12,7 \%, p = 0,045), сила (ЕГЛШ 22,6 \% проти КГЛШ 3,2 \%, p = 0,023).

Киючевые слова: кардиальное ремолелирование, физическое воспитание и обучение.

\section{Запорожский} медицинский журнал. 2020. T. 22, № 5(122). C. $643-651$

\section{Особенности кардиального ремоделирования в зависимости от направленности тренировочного процесса}

\section{С. Н. Малахова, В. В. Сыволап, М. С. Потапенко}

Различные виды физиологической адаптации сердца у атлетов формируются в зависимости от специфики спортивной деятельности. У спортсменов, тренирующихся в циклических, преимущественно аэробных видах спорта (бег на длинные дистанции, лыжный спорт, плавание), в основном развивается дилатация полости левого желудочка (ЛЖ) с пропорциональным увеличением толщины его стенок. Если в тренировке преобладают статические, или изометрические, нагрузки (тяжеловесы, единоборцы, метатели), у спортсменов развивается концентрическая гипертрофия с увеличением толщины стенки ЛЖ без изменения размера его полости. Однако изменения геометрии сердца у атлетов не ограничиваются только эксцентричной и концентрической гипертрофией ЛЖ.

Цель работы - изучение особенностей ремоделирования сердца спортсменов в зависимости от направленности тренировочного процесса (выносливость, скорость, сила).

Материалы и методы. После подписания информированного согласия в исследование включены 104 спортсмена (84 мужчины и 20 женщин): 63 - атлеты, которые развивали преимущественно качество выносливости; 31 - качество силы, 10 обследованных - качество скорости. Средний возраст спортсменов составил 21,75 $\pm 3,32$ года. Среди них мастеров спорта международного класса (МСМК) - 2 спортсмена, мастеров спорта (МС) - 25, кандидатов в мастера спорта - 48, спортсменов 1 разряда - 29 обследованных. Всем спортсменам проведено эхокардиографическое исследование в М, В режимах, допплерографическая оценка трансклапанных потоков, тканевой допплер.

Результаты. У спортсменов, которые развивали качество выносливости, в отличие от спортсменов, развивающих качество силы, преобладали размеры левого предсердия $(p=0,019)$, правого желудочка $(p=0,004)$, ИММЛЖ $(p=0,004)$, по остальным показателям разница не установлена. У спортсменов, которые развивали качество выносливости, в отличие от спортсменов, развивающих качество скорости, преобладала толщина МЖП ( $p=0,015)$, ИММЛЖ $(p=0,003)$, ФВ ЛЖ $(p=0,035)$, градиент давления ( $p=0,024)$ в аорте. У спортсменов, которые развивали качество силы, в отличие от атлетов, которые развивали качество скорости, на 10,8 \% ( $=$ = 0,004) преобладал конечный диастолический размер ЛЖ. Достоверно наибольшие размеры предсердий зарегистрированы у спортсменов, развивающих преимущественно качество выносливости, наименьшие - у спортсменов, развивающих качество силы $(p=0,019)$.

Выводы. Несмотря на длительные физические нагрузки, нормальная геометрия ЛЖ осталась у 90 \% (9/10) атлетов, которые совершенствовали качество скорости, у 74,2 \% (23/31) спортсменов, развивающих преимущественно качество силы, у 46,0 \% (29/63) атлетов, которые совершенствовали качество выносливости ( $p=0,012)$. Гипертрофия ЛЖ чаще возникала (47,6 \% против 25,8 \%, p = 0,044) у спортсменов, развивающих преимущественно качество выносливости, в отличие от спортсменов, совершенствующих качество силы. В структуре гипертрофии у спортсменов, развивающих качества и выносливости, и силы, достоверно преобладала эксцентрическая гипертрофия над концентрической: выносливость (ЭГЛЖ 34,9 \% против КГЛЖ 12,7 \%, p = 0,045), сила (ЭГЛЖ 22,6 \% против КГЛЖ 3,2%, p = 0,023).

Modern sports demand higher standards of the level of dynamic (endurance), static (power), speed and power performance which is limited by the complex functioning of the cardiovascular, respiratory, oxygen-transport, autonomic systems, the degree of emotional and mental stability of athletes. Surely, special attention should be paid to the study of structural-geometric and functional reorganization of the cardiovascular system in athletes under the influence of systematic exercise due to increased sympathetic stimulation of the neuromuscular system of the heart and blood vessels that reduces the efficiency of adaptive responses. An integral part of the rational adaptation of the circulatory system to sports in an athlete is physiological remodeling of the heart [2]. In recent years, the data on various forms of myocardial remodeling in athletes, depending on the mode of training session, race, gender, age, experience in sports $[15,28]$ have been accumulated.

Features of the cardiovascular system remodeling are extremely important to consider when assessing the current functional state of athletes to exclude both false-positive adaptive changes in the myocardium and incorrect medical disqualification of athletes. On the other hand, underestimation of pathological changes, unrelated to physiological heart remodeling but resulting in a decrease in athletic performance [2], in some cases, can cause sudden cardiac death in athletes [16].

\section{Aim}

The aim of this work - to study the features of heart remodeling in athletes depending on the mode of training session (endurance, speed, strength).

\section{Material and methods}

After the signing of the informed consent, 104 athletes (84 men and 20 women) were involved in the study: 63 - athletes who mainly trained endurance performance, 
31 - strength athletes, 10 - speed athletes. The mean age of the athletes was $21.75 \pm 3.32$ years. Among them, there were Masters of Sports of International Class (MSIC) -2 athletes, Masters of Sports (MS) - 25, Candidates Master of Sports (CMS) - 48, First-Class athletes -29.

The echocardiographic examination was performed in accordance with the updated recommendations of 2015 and 2016 American Society of Echocardiography and the European Association of Cardiovascular Imaging [19,24]. All the athletes underwent $\mathrm{M}$ - and B-mode echocardiographic examination, Doppler interrogation of transvalvular flows and tissue Doppler imaging.

Statistical processing of the study results was performed using a software package Statistica for Windows 13 (StatSoft Inc., No. JPZ804I382130ARCN10-J). The Shapiro-Wilk test was used to determine the normality of quantitative indicators distribution. Quantitative indicators were presented in the form of arithmetic mean and standard deviation based on the normality of the data distribution; qualitative indicators - in the form of absolute and relative frequency. Comparison of quantitative indicators in independent groups was determined by the method of parametric statistics using the two-sample Student's t-test with a two-sided test index for a statistical significance value. Measurement data of a non-normal distribution and non-linear dependence were expressed as a median and quartile $\left(\mathrm{Me}\left(Q_{25} ; Q_{75}\right)\right)$. To assess the differences in indicators, the nonparametric Mann-Whitney U-test was calculated as a nonparametric analogue of the Student criterion. Differences in qualitative characteristics in the independent groups were assessed using Pearson's chi-square test with Yates' correction and Fisher's exact test. The differences were considered statistically significant at a level of $\mathrm{P}<0.05$.

\section{Results}

Comparative analysis of structural-geometric and functional indicators of the heart between the endurance and strength athletes. Structural-geometric and functional indicators of the heart in the endurance athletes (Table 1) were characterized by a predominance of the left atrium (LA) diameter $(3.78 \pm 0.41$ vs. $3.55 \pm 0.53 \mathrm{~cm})$ by $6.1 \%(P=0.019)$, the diameter of the right ventricle (RV) $(2.40 \pm 0.55$ vs. $2.02 \pm 0.57$ $\mathrm{cm})$ by $15.8 \%(P=0.004)$, left ventricular myocardial mass index (LVMMI) $110.62 \pm 20.82$ vs. $\left.97.84 \pm 24.13 \mathrm{~g} / \mathrm{m}^{2}\right)$ by $11.6 \%(P=0.004)$ over these indicators in the strength athletes.

It is noteworthy, that there was no significant difference in EDD LV between the endurance athletes and strength athletes, $5.23 \pm 0.55 \mathrm{~cm}$ versus $5.36 \pm 0.53 \mathrm{~cm}$, respectively.

Higher LV MMI in the endurance athletes, unlike the strength athletes, was due to an increase in the LV PWd $(0.95 \pm 0.19$ vs. $0.88 \pm 0.19 \mathrm{~cm}, P=0.076)$ and IVST $(0.87 \pm 0.17$ vs. $0.82 \pm 0.21 \mathrm{~cm}, P=0.073)$. The differences were almost at the limit values of statistical significance. So, the predominance of LV MMI in the endurance athletes, unlike the strength athletes, resulted not from EDD LV, but from the LV wall thickening.

The endurance and strength athletes did not differ in terms of systolic function of the left ventricle (LV) (EF, Ao V, Ao G) and diastolic function (MV V, MV G, mean PAP).
Table 1. Differences in structural-geometric and functional parameters of the heart between the endurance and strength athletes, $M \pm S D$, $M e\left(Q_{25} ; Q 75\right)$

\begin{tabular}{|c|c|c|c|c|}
\hline \multirow{2}{*}{$\begin{array}{l}\text { Parameters, } \\
\text { units of measure }\end{array}$} & \multicolumn{2}{|l|}{ Performance } & \multirow[t]{2}{*}{ P-level } & \multirow[t]{2}{*}{$\Delta \%$} \\
\hline & Endurance $(n=63)$ & Strength $(n=31)$ & & \\
\hline $\mathrm{DAo}, \mathrm{cm}$ & $3.30 \pm 0.28$ & $3.01 \pm 0.43$ & 0.255 & \\
\hline LADd, cm & $3.78 \pm 0.41$ & $3.55 \pm 0.53$ & 0.019 & $+6.1 \%$ \\
\hline EDD LV, cm & $5.23 \pm 0.55$ & $5.36 \pm 0.53$ & 0.296 & \\
\hline ESD LV, cm & $3.26 \pm 0.42$ & $3.31 \pm 0.49$ & 0.748 & \\
\hline LV PWd, cm & $0.95 \pm 0.19$ & $0.88 \pm 0.16$ & 0.076 & \\
\hline IVST, cm & $0.87 \pm 0.17$ & $0.82 \pm 0.21$ & 0.073 & \\
\hline LV EF, \% & $67.24 \pm 5.61$ & $67.68 \pm 7.12$ & 0.626 & \\
\hline $\mathrm{RV}, \mathrm{cm}$ & $2.40 \pm 0.55$ & $2.02 \pm 0.57$ & 0.004 & $+15.8 \%$ \\
\hline RV wall, cm & $0.22 \pm 0.05$ & $0.23 \pm 0.11$ & 0.679 & \\
\hline LV MMI, g/m² & $110.62 \pm 20.82$ & $97.84 \pm 24.13$ & 0.004 & $+11.6 \%$ \\
\hline E/AMV, r.u. & $2.14 \pm 0.51$ & $2.18 \pm 0.54$ & 0.994 & \\
\hline E/E' med. & $5.91 \pm 1.41$ & $6.66 \pm 1.80$ & 0.091 & \\
\hline E/E' lat. & $4.45 \pm 0.79$ & $4.47 \pm 0.82$ & 0.725 & \\
\hline MV V, m/s & $0.83 \pm 0.14$ & $0.89 \pm 0.16$ & 0.061 & \\
\hline MV G, mm Hg & $2.84 \pm 1.19$ & $3.24 \pm 1.17$ & 0.867 & \\
\hline Ao $V, m / s$ & $1.17 \pm 0.25$ & $1.13 \pm 0.23$ & 0.353 & \\
\hline Ao $\mathrm{G}, \mathrm{mm} \mathrm{Hg}$ & $5.67 \pm 2.34$ & $5.28 \pm 2.21$ & 0.403 & \\
\hline TV V, m/s & $0.56 \pm 0.12$ & $0.54 \pm 0.11$ & 0.815 & \\
\hline TV G, mm Hg & $1.35 \pm 0.69$ & $1.21 \pm 0.48$ & 0.660 & \\
\hline $\mathrm{PAV}, \mathrm{m} / \mathrm{s}$ & $0.89 \pm 0.21$ & $0.90 \pm 0.15$ & 0.690 & \\
\hline PA G, mm Hg & $3.41 \pm 1.41$ & $3.34 \pm 1.12$ & 0.952 & \\
\hline Mean PAP, mm Hg & $11.2(9.4 ; 15.7)$ & $13.6(9.4 ; 16.7)$ & 0.428 & \\
\hline IVC, $\mathrm{mm}$ & $19.05 \pm 4.42$ & $17.02 \pm 4.25$ & 0.101 & \\
\hline
\end{tabular}

DA0: diameter of aorta; LADd: left atrial diameter in diastole; EDD LV: end-diastolic diameter of the left ventricle; ESS LV: end-systolic diameter of the left ventricle; LV PWd: diastolic left ventricular posterior wall thickness; IVST: interventricular septal thickness; LV EF: left ventricular ejection fraction;

RV: right ventricular diameter; RV wall: right ventricular free wall thickness; LV MMI: left ventricular myocardial mass index; E/A MV: ratio of early left ventricular filling velocity to atrial systole; E/E': ratio of early left ventricular filling velocity to the mitral annular early diastolic velocity (lateral and medial); MV V and MV G: blood flow velocity and transmitral pressure gradient in the period of early filling of the left ventricle; $\mathrm{A}_{0} \mathrm{~V}$ and $\mathrm{Ao} \mathrm{G}$ : blood flow velocity in the aorta and transaortic pressure gradient; TV V and TV G: blood flow velocity and transtricuspidal pressure gradient in the period of early filling of the right ventricle; PA V and PA G: pulmonary artery blood flow velocity and transpulmonary pressure gradient; mean PAP: mean pulmonary artery pressure; IVC: diameter of the inferior vena cava.

Thus, in the endurance athletes, unlike the strength athletes, the diameter of $L A(P=0.019)$ and $L V(P=0.004)$, and LV MMI $(P=0.004)$ prevailed. They also had lower indicators of IVST $(P=0.073)$, LV PWd $(P=0.076)$, end-diastolic pressure in the LV $(P=0.091)$, but only as a trend.

Comparative analysis of structural-geometric and functional indicators of the heart between the endurance and speed athletes revealed the following differences (Table 2). In the endurance athletes, LV MMI was significantly $27.4 \%$ $(P=0.003)$ higher $\left(110.62 \pm 20.82\right.$ vs. $\left.80.30 \pm 33.68 \mathrm{~g} / \mathrm{m}^{2}\right)$, than that in the speed athletes. The significant increase in LV MMI in the endurance athletes probably contributed to the larger IVST $(0.87 \pm 0.17$ vs. $0.74 \pm 0.12 \mathrm{~cm})$ by $14.9 \%$ $(P=0.015)$ and the trend towards EDS LV predominance $(5.23 \pm 0.55$ vs. $4.78 \pm 0.51 \mathrm{~cm})$ by $8.6 \%(P=0.058)$ over these indicators in the speed athletes.

The predominance of LV MMI in the endurance athletes (Table 2) was associated with a significant increase in Ao $\mathrm{G}$ by $29.9 \%(P=0.024)(5.67 \pm 2.34$ vs. $3.97 \pm 1.63 \mathrm{~mm}$ $\mathrm{Hg})$ and a trend towards increasing Ao V $(1.17 \pm 0.25 \mathrm{vs}$. $1.03 \pm 0.33 \mathrm{~m} / \mathrm{s})$ by $11.9 \%(P=0.055)$.

Thus, in the endurance athletes, unlike the speed athletes, the IVST $(P=0.015)$, LV MMI $(P=0.003)$, EDD LV $(P=0.058)$, Ao V $(P=0.055)$ and $A o G(P=0.024)$ prevailed indicating better pumping function of the LV due to more pronounced LV hypertrophy. 
Table 2. Differences in structural-geometric and functional parameters of the heart between the endurance and speed athletes, $M \pm S D, M e\left(Q_{25} ; Q_{75}\right)$

\begin{tabular}{|c|c|c|c|c|}
\hline \multirow{2}{*}{$\begin{array}{l}\text { Parameters, } \\
\text { units of measure }\end{array}$} & \multicolumn{2}{|l|}{ Performance } & \multirow[t]{2}{*}{ P-level } & \multirow[t]{2}{*}{$\Delta \%$} \\
\hline & Endurance $(n=63)$ & Speed $(n=10)$ & & \\
\hline $\mathrm{DAo}, \mathrm{cm}$ & $3.30 \pm 0.28$ & $2.54 \pm 0.39$ & 0.002 & $+23.0 \%$ \\
\hline LADd, cm & $3.78 \pm 0.41$ & $3.66 \pm 0.63$ & 0.382 & \\
\hline EDD LV, cm & $5.23 \pm 0.55$ & $4.78 \pm 0.51$ & 0.058 & \\
\hline ESD LV, cm & $3.26 \pm 0.42$ & $3.14 \pm 0.34$ & 0.399 & \\
\hline LV PWd, cm & $0.95 \pm 0.19$ & $0.93 \pm 0.28$ & 0.297 & \\
\hline IVST, cm & $0.87 \pm 0.17$ & $0.74 \pm 0.12$ & 0.015 & $+14.9 \%$ \\
\hline LV EF, \% & $67.24 \pm 5.61$ & $63.40 \pm 3.24$ & 0.035 & $+5.7 \%$ \\
\hline $\mathrm{RV}, \mathrm{cm}$ & $2.40 \pm 0.55$ & $2.78 \pm 1.87$ & 0.537 & \\
\hline $\mathrm{RV}$ wall, $\mathrm{cm}$ & $0.22 \pm 0.05$ & $0.20 \pm 0.03$ & 0.370 & \\
\hline LV MMI, g/m² & $110.62 \pm 20.82$ & $80.30 \pm 33.68$ & 0.003 & $+27.4 \%$ \\
\hline E/A MV, r.u. & $2.14 \pm 0.51$ & $2.34 \pm 0.48$ & 0.279 & \\
\hline E/E' med. & $5.91 \pm 1.41$ & $6.30 \pm 1.86$ & 0.526 & \\
\hline E/E' lat. & $4.45 \pm 0.79$ & $4.10 \pm 0.91$ & 0.279 & \\
\hline MV V, m/s & $0.83 \pm 0.14$ & $0.88 \pm 0.16$ & 0.390 & \\
\hline MV G, mm Hg & $2.84 \pm 1.19$ & $3.17 \pm 1.18$ & 0.123 & \\
\hline Ao $V, m / s$ & $1.17 \pm 0.25$ & $1.03 \pm 0.33$ & 0.055 & \\
\hline Ao $\mathrm{G}, \mathrm{mm} \mathrm{Hg}$ & $5.67 \pm 2.34$ & $3.97 \pm 1.63$ & 0.024 & $+29.9 \%$ \\
\hline TV V, m/s & $0.56 \pm 0.12$ & $0.55 \pm 0.16$ & 0.676 & \\
\hline TV G, mm Hg & $1.35 \pm 0.69$ & $1.33 \pm 0.91$ & 0.735 & \\
\hline $\mathrm{PA} V, \mathrm{~m} / \mathrm{s}$ & $0.89 \pm 0.21$ & $0.82 \pm 0.14$ & 0.175 & \\
\hline PA G, mm Hg & $3.41 \pm 1.41$ & $2.79 \pm 0.94$ & 0.137 & \\
\hline Mean PAP, mm Hg & $11.2(9.4 ; 15.7)$ & $13.35(9.4 ; 16.7)$ & 0.412 & \\
\hline IVC, mm & $19.05 \pm 4.42$ & $17.56 \pm 3.32$ & 0.373 & \\
\hline
\end{tabular}

Table 3. Differences in structural-geometric and functional parameters of the heart between the strength and speed athletes, $M \pm S D, M e\left(Q_{25} ; Q_{75}\right)$

\begin{tabular}{|c|c|c|c|c|}
\hline \multirow{2}{*}{$\begin{array}{l}\text { Parameters, } \\
\text { units of measure }\end{array}$} & \multicolumn{2}{|l|}{ Performance } & \multirow[t]{2}{*}{ P-level } & \multirow[t]{2}{*}{$\Delta \%$} \\
\hline & Strength $(n=31)$ & Speed $(n=10)$ & & \\
\hline $\mathrm{DAo}, \mathrm{cm}$ & $3.01 \pm 0.43$ & $2.54 \pm 0.39$ & 0.004 & $+15.6 \%$ \\
\hline LADd, cm & $3.55 \pm 0.53$ & $3.66 \pm 0.63$ & 0.606 & \\
\hline EDD LV, cm & $5.36 \pm 0.53$ & $4.78 \pm 0.51$ & 0.004 & $+10.8 \%$ \\
\hline ESD LV, cm & $3.31 \pm 0.49$ & $3.14 \pm 0.34$ & 0.346 & \\
\hline LV PWd, cm & $0.88 \pm 0.16$ & $0.93 \pm 0.28$ & 0.891 & \\
\hline IVST, cm & $0.82 \pm 0.21$ & $0.74 \pm 0.12$ & 0.457 & \\
\hline LVEF, \% & $67.68 \pm 7.12$ & $63.40 \pm 3.24$ & 0.068 & $+6.3 \%$ \\
\hline $\mathrm{RV}, \mathrm{cm}$ & $2.02 \pm 0.57$ & $2.78 \pm 1.87$ & 0.141 & \\
\hline RV wall, cm & $0.23 \pm 0.11$ & $0.20 \pm 0.03$ & 0.551 & \\
\hline LV MMI, g/m² & $97.84 \pm 24.13$ & $80.30 \pm 33.68$ & 0.370 & \\
\hline E/A MV, r.u. & $2.18 \pm 0.54$ & $2.34 \pm 0.48$ & 0.182 & \\
\hline E/E' med. & $6.66 \pm 1.80$ & $6.30 \pm 1.86$ & 0.553 & \\
\hline E/E' lat. & $4.47 \pm 0.82$ & $4.10 \pm 0.91$ & 0.271 & \\
\hline $\mathrm{MV} V, \mathrm{~m} / \mathrm{s}$ & $0.89 \pm 0.16$ & $0.88 \pm 0.16$ & 0.738 & \\
\hline MV G, mm Hg & $3.24 \pm 1.17$ & $3.17 \pm 1.18$ & 0.820 & \\
\hline Ao $V, m / s$ & $1.13 \pm 0.23$ & $1.03 \pm 0.33$ & 0.128 & \\
\hline Ao $\mathrm{G}, \mathrm{mm} \mathrm{Hg}$ & $5.28 \pm 2.21$ & $3.97 \pm 1.63$ & 0.078 & \\
\hline TV V, m/s & $0.54 \pm 0.11$ & $0.55 \pm 0.16$ & 0.761 & \\
\hline TV G, mm Hg & $1.21 \pm 0.48$ & $1.33 \pm 0.91$ & 0.939 & \\
\hline $\mathrm{PA} \mathrm{V}, \mathrm{m} / \mathrm{s}$ & $0.90 \pm 0.15$ & $0.82 \pm 0.14$ & 0.136 & \\
\hline $\mathrm{PA} \mathrm{G}, \mathrm{mm} \mathrm{Hg}$ & $3.34 \pm 1.12$ & $2.79 \pm 0.94$ & 0.171 & \\
\hline Mean PAP, mm Hg & $13.60(9.40 ; 16.70)$ & $13.35(9.4 ; 16.70)$ & 0.987 & \\
\hline IVC, mm & $17.02 \pm 4.25$ & $17.56 \pm 3.32$ & 0.871 & \\
\hline
\end{tabular}

Comparative analysis of structural-geometric and functional indicators of the heart between the strength and speed athletes. Analysis of structural-geometric and functional indicators of the heart between the strength and speed athletes (Table 3) showed a significant predominance of
EDD LV by $10.8 \%(P=0.004)(5.36 \pm 0.53$ vs. $4.78 \pm 0.51$ $\mathrm{cm}$ ) as compared to the strength athletes.

At the same time, there was a trend to the predominance of LV EF $(67.68 \pm 7.12$ vs. $63.40 \pm 3.24 \%, P=0.068)$ and $A o G(5.28 \pm 2.21$ vs. $3.97 \pm 1.63 \mathrm{~mm} \mathrm{Hg}, P=0.078)$.

According to the structural indicators (LV MMI, IVST, LV PWd) and indicators of LV diastolic function (E/A, E/E', mean PAP), the strength and speed athletes did not differ from each other.

Thus, in the strength athletes, unlike the speed athletes, EDD LV $(P=0.004)$, LV EF ( $P=0.068)$, Ao G $(P=0.078)$ prevailed indicating better $L V$ systolic function, an improvement of which was realized through the Frank-Starling mechanism, namely by increasing EDD LV $(P=0.004)$.

Obtained results strongly suggest that the performance (endurance, speed, strength), mainly trained by athletes, significantly affect the structural-geometric and functional reorganization of the heart, and these changes relate not only to the LV.

Thus, the largest LADd was registered in the endurance athletes, the smallest - in the strength athletes. The intermediate values of the LADd were in the speed athletes (Fig. 1).

The largest EDD LV was detected in the endurance athletes, the smallest - in the speed athletes. The strength athletes did not differ from the endurance athletes in terms of EDD LV (Fig. 2).

The most significant increase in the LV MMI (due to both the cavity dilation and increase in the wall thickness (Fig. 4)) was observed in the endurance athletes (Fig. 3).

A less marked increase in LV MMI was found in the strength athletes (due to the increase in the LV wall thickness, rather than its cavity (Fig. 2)). The strength and speed athletes did not differ in LV MMI from each other (Fig. 3).

The highest values of LV EF were demonstrated by the endurance and strength athletes, unlike the speed athletes (Fig. 5).

In terms of LV diastolic function, the endurance, strength and speed athletes did not differ in haemodynamical profile of the pulmonary circulation from each other. All the athletes showed mean values of $E / E$ ' med. within the reference ranges (Fig. 6). This indicator reflects the end-diastolic pressure in the LV and is a very sensitive marker of its diastolic filling disorders, which occur due to increased myocardial mass and/or dilation of the LV cavity.

Despite the fact, that the endurance athletes demonstrated the highest indicators of LV MMI and EDDLV, the mean value of E/E' med. was the lowest, indicating the lowest level of end-diastolic pressure in the LV.

So, the features of structural and geometric remodeling of the heart in the endurance athletes should be considered as increase in LADd, EDD LV, LV MMI due to both the cavity dilation and increase in the wall thickness.

The strength athletes showed the lowest mean LADd and LV PWd and the highest mean values of EDD LV, LV EF and the E/E' med. ratio. According to the LV MMI, the strength athletes placed between the endurance and speed athletes.

The speed athletes were revealed with the smallest EDD LV, LV MMI, LV EF in comparison with the endurance and strength athletes. 


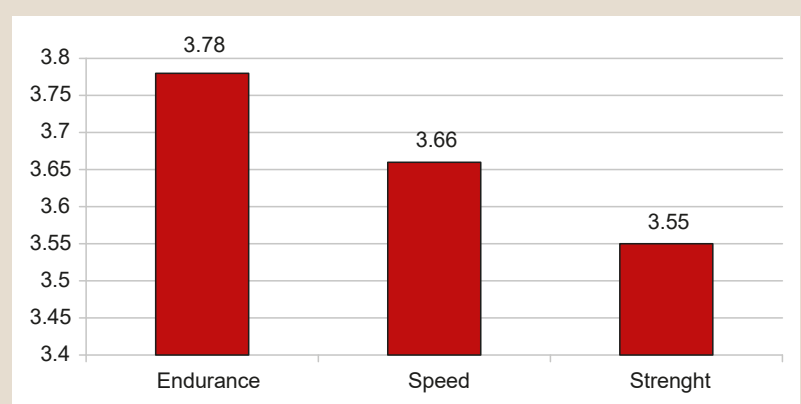

Fig. 1. Dependence of the left atrium diameter on the physical performance mainly trained by the athletes (endurance, speed, strength). There is a statistically significant difference only between the indicators of LADd in the endurance and strength athletes.

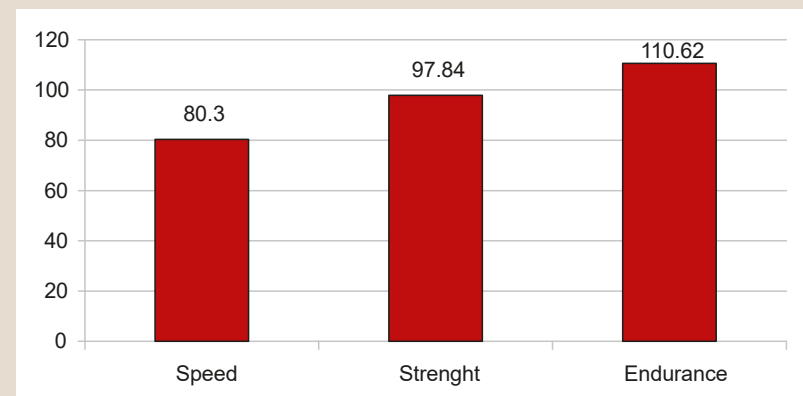

Fig. 3. Dependence of the LV MMI on the physical performance mainly trained by the athletes (endurance, speed, strength). There are statistically significant differences between the indicators of LV MMI in the endurance and speed athletes, as well as in the endurance and strength athletes.

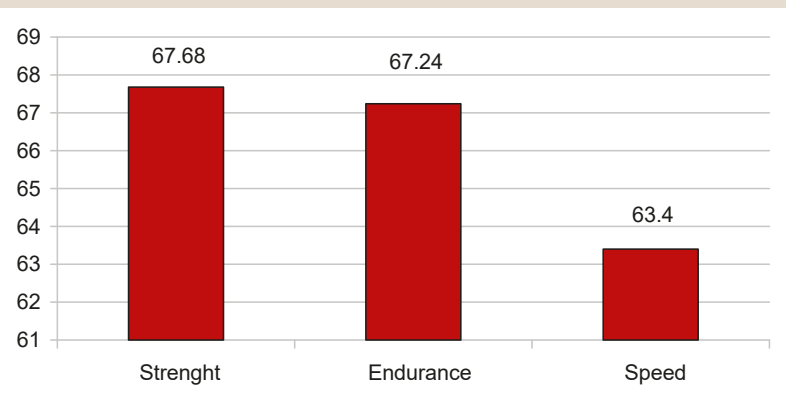

Fig. 5. Dependence of the left ventricular ejection fraction on the physical performance mainly trained by the athletes (endurance, speed, strength). There are statistically significant differences between the indicators of LV EF in the endurance and speed athletes, as well as in the strength and speed athletes.

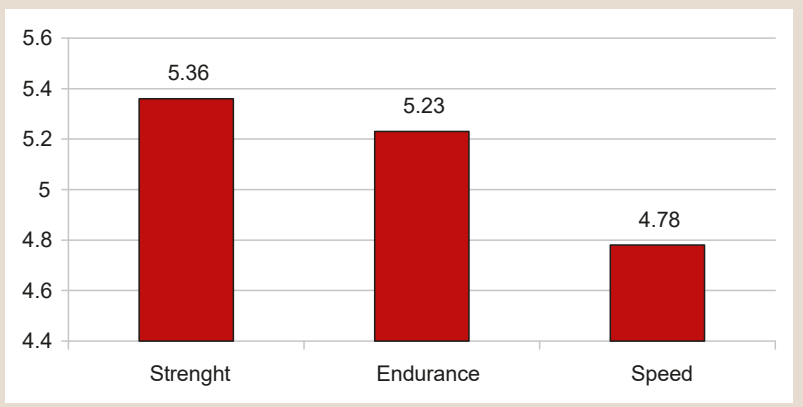

Fig. 2. Dependence of the end-diastolic diameter of the left ventricle on the physical performance mainly trained by the athletes (endurance, speed, strength). There are statistically significant differences between the indicators of EDD LV in the endurance and speed athletes, as well as in the strength and speed athletes.

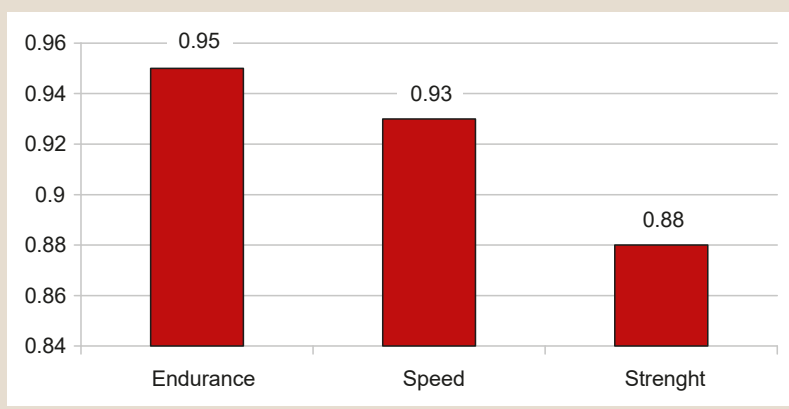

Fig. 4. Dependence of diastolic left ventricular posterior wall thickness on the physica performance mainly trained by the athletes (endurance, speed, strength). There are no statistically significant differences between the indicators of LV PWd in the endurance, strength and speed athletes.

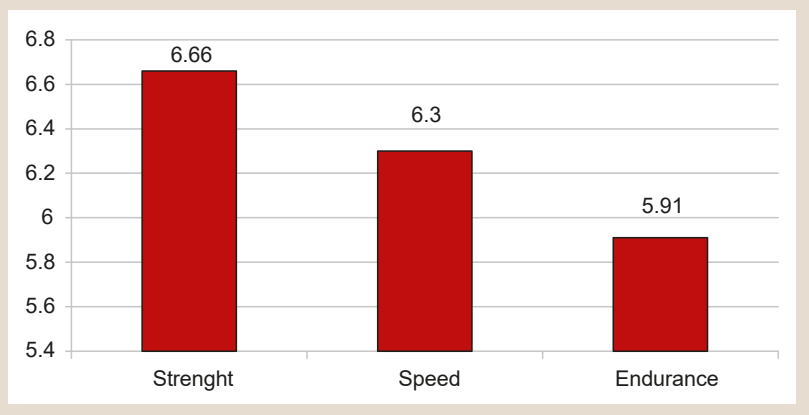

Fig. 6. Dependence of E/E' med. on the physical performance mainly trained by the athletes (endurance, speed, strength). There are no statistically significant differences between the indicators.

\section{Discussion}

Numerous adaptive reactions in the cardiovascular system occur due to regular training loads of dynamic (endurance) and static (strength) nature. Heart size, systolic volume, circulating blood volume, blood flow, cardiac output, heart rate, blood pressure are changing [2].

Physiological changes depend on such factors as age, sex, body type, kind of sport, and, in most cases, are within reference ranges. Different types of physiological adaptation of the heart in athletes are formed depending on the specifics of sports activities. Athletes training in cyclic, mostly aerobic sports (long-distance running, skiing, swimming), mainly develop dilation of the LV cavity with a proportional increase in the thickness of its wall. This is due to increased cardiac output during exercise, i.e. LV volume overload as well as increased systemic blood pressure, and eccentric LV hypertrophy develops without change in the ratio of LV wall thickness to its diameter [7]. In this case, hypertrophy is the result of addition of sarcomeres in series and longitudinal cell growth [17].

In $20 \%$ of athletes training mainly endurance with a sports experience of more than 6000 hours, there is an upper limit exceeding the normal LA size in the general population [15].

The main difference between the cardiovascular system responses to isometric (static) exercises, compared with dynamic exercises (endurance), is the different effects on active muscular blood flow. During isometric contraction, muscle blood flow decreases in response to the stiffness of active muscle fibers, which increases intramuscular pressure and causes mechanical vasoconstriction. Static 
exercise can significantly increase both systolic and diastolic blood pressure during exercise, but normally it does not lead to an increase in resting blood pressure. During an intensive static loading, the maximum oxygen consumption does not change or slightly increases. The impact of volume remains relatively stable, but it may decrease during high-intensity training as a result of rising after exercise [2].

Athletes, whose trainings are dominated by static or isometric loads (weightlifters, wrestlers, throwers), develop concentric hypertrophy with increasing LV wall thickness, without changes in the size of its cavity, which is caused by an increased heart afterload resulted from increased systemic blood pressure during exercises [7]. Although the prevalence of high blood pressure is approximately $50 \%$ lower in athletes than in the general population, it is also the most common cardiovascular condition in athletes [25]. Possibly, myocardial hypertrophy in athletes may be caused by increased blood pressure, which is confirmed by a number of studies that have shown a large majority of athletes with hypertensive stress response LV myocardial mass than athletes with normotensive reaction [7].

Regular static loads contribute to the formation of predominantly concentric myocardial hypertrophy (the value of EDD LV varies slightly), which often requires differential diagnosis between a number of pathological conditions. The increase in mass in this case is a consequence of hypertrophy of existing myocytes, rather than an increase in their number [23].

Surely, LV hypertrophy is a reaction to conditions that force the heart muscle to work harder. High-intensity training can cause the heart to adapt, which compensates for the increase in blood pressure or volume by increasing muscle mass [12].

Physiological LV hypertrophy is characterized by an increase in extracellular tissue in proportion to myocyte hypertrophy, and there is no detrimental effect on LV function [10]. Physiological LV hypertrophy may be a normal response to growth signals (eg, postnatal growth or prolonged exercise), allowing the heart to increase its pumping function [10].

Pathological LV hypertrophy develops in response to stress signals (hypertension or myocardial infarction). Pathological LV hypertrophy is also found in patients with genetic diseases, such as hypertrophic cardiomyopathy that can be caused by mutations in genes encoding sarcomere proteins [11]. In pathological LV hypertrophy, the extracellular matrix increases relative to myocytes, but the rate of capillary growth is slower, and adaptation becomes insufficient to meet the load [10].

Thus, in heart disease, the basis of its remodeling is the structural and functional reconstruction of both cardiomyocyte and interstitial components of the myocardium. However, cardiomyocyte remodeling does not always occur in parallel with changes in the cardiac interstitial elements. So, the hypertrophy of cardiomyocytes is not associated with a simultaneous increase in the interstitial component mass in every case. Isolated growth of the interstitial matrix is possible, in particular in coronary vasculitis and radiation cardiopathy [1]. In pathological conditions associated with heart volumetric overload, cardiomyocyte hypertrophy is usually not accompanied by the growth of fibroblasts and collagen concentration remains within normal limits for a long time. In cases of pressure overload, myocyte hyper- trophy is associated with reactive fibrosis and increased collagen concentrations [1]. The concentric variant of LV hypertrophy is characterized by a proportional increase in muscular, vascular and interstitial components of the myocardium. These changes are considered adaptive, which is evidenced by the return of the LV cavity to its original values while eliminating an increased load on the heart. However, as soon as the growth of the non-myocyte component becomes excessive, the hypertrophy becomes pathological [3].

For differential diagnosis between pathological and physiological LV hypertrophy, tissue Doppler of the mitral annulus is used. In patients with pathological LV hypertrophy, systolic and early diastolic velocities of the mitral annulus movement decrease, that is not observed in athletes with physiological LV hypertrophy. Decreased systolic velocity of the mitral annulus movement less than $9 \mathrm{~cm} / \mathrm{s}$ is a highly specific marker of pathological LV hypertrophy [5].

Myocardial fibrosis and scarring are a common mechanism for reducing ventricular compliance and increasing filling pressure. Filling pressure is assessed using a combination of parameters and an algorithm for normal or elevated LA pressure and LV end-diastolic pressure. To characterize the increase in LV filling pressure, the following parameter values are recommended: LA volume index more than $34 \mathrm{ml} / \mathrm{m}$, increased tricuspid valve (TV) regurgitation velocity more than $2.8 \mathrm{~m} / \mathrm{s}$; the average E/E' more than 14 [24].

La Gerche and co-authors used magnetic resonance imaging to detect myocardial fibrosis in athletes, who had been competing for a long time. It is well known, that myocardial fibrosis can be a substrate for ventricular tachycardia and sudden death in susceptible individuals [18]. Along with fibrosis, athletes were also diagnosed with decreased RV function, which allowed researchers to suggest, that the heart has a limited ability to maintain increased exercise requirements. Based on this conclusion, some authors [27] proposed a new type of cardiomyopathy - "Phidippides cardiomyopathy" - repeated prolonged stress causes dilation of the heart chambers and stimulates resident macrophages, pericytes and fibroblasts, which leads to collagen deposition, i.e. causes focal fibrosis $[21,27]$.

Observations of elite athletes have shown, that diffuse myocardial fibrosis, despite normal coronary arteries, was registered 4.6 times more often, than in control groups, occupying up to $10 \%$ of the heart muscle volume [13]. In separate sports populations, cases of fibrosis reaches $50 \%$ [14], especially in athletes with large and prolonged loads aimed at developing the endurance performance.

Such changes do not disrupt the myocardium global function, but in fibro-modified areas there is a regional dysfunction, manifested as changes in stress and longitudinal gradient in the myocardium, and LV end-diastolic volume and relative wall thickness are significantly higher in these cases, than those in athletes without myocardial fibrosis. Fibrosis is more often observed in myocardial hypertrophy, because the latter is often combined with apoptosis and necrosis of cardiomyocytes, the loss of which is compensated by an excessive collagen deposition and fibroblast accumulation [9].

The main mechanism for the fibrosis development in athletes is ischemia. However, unlike cardiac patients, coronary atherosclerosis and a decrease in coronary perfusion 
due to reduced diastole amid tachycardia are not in the first place; deterioration of tissue perfusion is due to a decrease in the density of capillaries per unit volume of hypertrophied myocardium, insufficient angiogenesis in the myocardium in the advanced phase of hypertrophy, compression and necrosis of small coronary arteries resulted from an increase in the intramural pressure gradient during vigorous contractions of the hypertrophied myocardium $[12,20]$.

In addition, a diameter of the main coronary arteries does not increase after reaching a certain age. As a result of this limitation, even if new capillaries are formed, they can not be provided with sufficient volumetric blood flow from the proximal vessels. With prolonged and intense endurance loads, the levels of troponin and other biomarkers increase, which indicates possible damage to the «compressed» cardiomyocytes, ventricular deformation, or increased permeability of cell membranes [26,29]. Such repeated microtraumas can lead to widespread connective tissue changes in the heart muscle.

Another mechanism leading to ischemia, necrosis, and fibrosis may be elevated catecholamine levels and coronary vasospasm [22].

It should be noted, that blood pressure is at a higher level during exercise, than in everyday circumstances, and hypertension in athletes is not uncommon, therefore all of these combine to cause myocardial fibrosis [9].

According to A.V. Smolenskiy, a prevalence of increased left ventricular myocardial mass and high blood pressure in speed and strength athletes, characterized by a high amount of isometric training loads, are higher, than in cyclic sports athletes with a predominantly aerobic mode. Regularities of athlete's heart formation are contributed to the direction of training and competitive activities and generally do not lead to systolic and diastolic dysfunction, but increased blood pressure in athletes increases the risk of myocardial hypertrophy and myocardial remodeling, which is one of the possible contraindications for high sports loads [8].

Researchers [4] compared the mean values of heart morphometry in elite athletes and athletes with different modes (speed, speed-strength, mainly endurance training) of the training session and revealed that elite speed athletes were more likely to have an increased anterior-posterior diameter of the LA and RV, as well as LV PW in systole in comparison with these indicators in competitive athletes. The heart of the elite athletes with speed-strength mode of the training session was characterized by increased diameter of the aortic valve annulus and the anteroposterior diameter of the LA, i.e. there was a dilation of the LA along with normal LV volume. In athletes training mainly endurance, all the linear heart sizes were significantly increased (except for the left atrioventricular orifice diameter in diastole and systole), indicating the LV dilation and increased myocardial stretching.

According to O. O. Ronzhina and N. V. Fomina (2012), in athletes (21 (18.5-25.0) years), who were engaged in weightlifting, the average values of the heart cavities size did not exceed normal values, but were significantly higher, than those in the comparison group (age-matched students who did not practice sports). In the group of athletes, systolic LV function was normal and amounted to $69 \%$ (64-73\%); there were no signs of diastolic dysfunction; the normal LV geometry was found in 49 people $(61.2 \%)$, signs of concentric myocardial remodeling - in 14 (17.5\%), concentric hypertrophy - in 10 (12.5\%), eccentric hypertrophy - in 7 $(8.7 \%)$ athletes. The experience of weightlifting in the subgroup with normal LV geometry was 6 years (5-10 years), and in the subgroup with concentric hypertrophy -12.5 years $(10-19$ years $),(P<0.0001)$. The experience in athletes with concentric remodeling was 8.5 years $(7.0-10.0$ years), and with eccentric hypertrophy -6.0 years (3.0-18.0 years), no statistically significant differences were obtained. The authors hypothesized, that the development of the most prognostically unfavorable variant - concentric LV hypertrophy - directly depends on the time of exposure to strength loads [6].

The results of our own study showed, that $46 \%(29 / 63)$ of the endurance athletes had a normal geometry of the LV, average values $(M \pm S D)$ of the E/E' ratio $-5.63 \pm 1.55$, LV MMI $-93.3 \pm 23.60 \mathrm{~g} / \mathrm{m}^{2}$, LV relative wall thickness $0.32 \pm 0.07$; the proportion of concentric remodeling was $6.4 \%(4 / 63)$. The athletes with concentric remodeling did not differ in the E/E' ratio $5.69 \pm 1.60$ and LV MMI $105.00 \pm$ $32.03 \mathrm{~g} / \mathrm{m}^{2}$ from the athletes with normal geometry, but the LV relative wall thickness was significantly higher than normal ranges $(0.47 \pm 0.07$ r.u. versus 0.42 r.u. $)$. LV hypertrophy was registered in $47.6 \%$ (30/63) of the endurance athletes, the vast majority of whom had eccentric hypertrophy $34.9 \%$ (22/63), and the other $12.7 \%$ (8/63) concentric hypertrophy. There was no statistically significant difference between LV MMI and E/E' in the athletes with eccentric and concentric hypertrophy $\left(128.60 \pm 22.76 \mathrm{~g} / \mathrm{m}^{2}\right.$ vs. $\left.126.60 \pm 23.06 \mathrm{~g} / \mathrm{m}^{2}\right)$, and $(6.24 \pm 1.57$ vs. $6.17 \pm 1.51)$, respectively. Despite the absence of a difference between the mean values of the E/E' ratio in the athletes with eccentric and concentric LV hypertrophy, in $18.2 \%(4 / 22)$ of the athletes with eccentric LV hypertrophy, the value of this indicator exceeded 8 r.u., and only in $12.5 \%(1 / 8)$ of the athletes with concentric hypertrophy, but insignificantly $(P=0.698)$. An increase in the anterior-posterior diameter of the LA was detected in $27 \%(17 / 63)$ of the endurance athletes. No cases of increased LV end-diastolic pressure were diagnosed. In $100 \%(n=63)$ of the endurance athletes, the indicator $E / E$ ' did not exceed 15 r.u.

That is, in most endurance athletes, LV hypertrophy was absent either in the normal LV geometry (46\%) or concentric LV remodeling (6.4\%). $47.6 \%$ (30/63) of the endurance athletes had LV hypertrophy with a significant $(P=0.005)$ predominance of eccentric hypertrophy (34.9\%) over concentric hypertrophy $(12.7 \%)$. LA dilation greater than $4 \mathrm{~cm}$ was detected in $27 \%$ of the athletes, and LV dilation greater than $6 \mathrm{~cm}-$ in $8 \%$ of the athletes. Structural and geometric reconstruction of the heart was not accompanied by an increase in the LV end-diastolic pressure or LV systolic and diastolic function disorders.

The strength athletes had a normal LV geometry in $74.2 \%$ (23/31): LV MMI $-86.10 \pm 24.95 \mathrm{~g} / \mathrm{m}^{2}$, LV relative wall thickness $-0.30 \pm 0.07$, the $E / E$ ' ratio -6.87 . No case of concentric remodeling was diagnosed. LV hypertrophy was found in $25.8 \%$ (8/31) of cases: eccentric hypertrophy - in $22.6 \%(7 / 31)$, concentric hypertrophy - in $3.2 \%$ (1/31). In the athletes with concentric hypertrophy, LV MMI was $128 \mathrm{~g} / \mathrm{m}^{2}$, and the E/E' ratio exceeded the value of 8 r.u. (9.24). In the athletes with eccentric hypertrophy, 
the mean LV MMI values were $132.00 \pm 32.03 \mathrm{~g} / \mathrm{m}^{2}$, and the $E / E$ ' ratio $-5.65 \pm 1.60$. Dilation of the $L A$ was observed in $22.6 \%(7 / 31)$, the LV larger than $6.0 \mathrm{~cm}$ - in $16.1 \%$ $(5 / 31)$ of the strength athletes. No cases of the LV systolic or diastolic function disorders were observed.

Thus, the endurance or strength training did not affect the LV normal geometry in $74.2 \%(23 / 31)$ of the strength athletes and in $46.0 \%(29 / 63)$ of the endurance athletes $(P=0.012)$. Meanwhile, the endurance athletes, as compared to the strength athletes, were significantly more likely to have LV hypertrophy (47.6 \% vs. $25.8 \%, P=0.044)$. In the structure of hypertrophy in both the endurance and strength athletes, eccentric LV hypertrophy significantly prevailed over concentric hypertrophy: endurance - 34.9\% vs. $12.7 \%, P=0.045$, respectively; strength $-22.6 \%$ vs. $3.2 \%, P=0.023$, respectively. Presumably, this distribution of LV hypertrophy occurrence was due to genetic factors, which requires further study.

Despite the higher incidence rate of eccentric (endurance $34.9 \%$ vs. strength $22.6 \%, P=0.240$ ) and concentric (endurance $12.7 \%$ vs. strength $3.2 \%, P=0.127$ ) hypertrophy in the endurance athletes, the difference was below the level of significance (perhaps because of the low statistical power of the study) when compared with indicators of the strength athletes.

So, our findings indicate that regardless of the training session direction in the endurance and strength athletes, both eccentric and concentric LV hypertrophy was detected with a greater proportion of the former. These results necessitate clarifications and additions to existing statements that physiological eccentric LV hypertrophy is more common in athletes, engaged in endurance training (long-distance running or swimming). Those, who are engaged in strength training (weightlifting and wrestling), are more likely to develop concentric LV hypertrophy [11].

It should also be emphasized, that in the endurance athletes, LV hypertrophy occurred 1,8 times more often than in the strength athletes (according to our data).

No case of eccentric hypertrophy or concentric LV remodeling was diagnosed in the speed athletes. The vast majority of the athletes $(90 \%(9 / 10))$ had the normal LV geometry: LV MMI $-75.90 \pm 32.03 \mathrm{~g} / \mathrm{m}^{2}$, LV relative wall thickness $-0.34 \pm 0.07$, the E/E' ratio $-5.84 \pm 1.61$. Concentric LV hypertrophy was registered only in one case: LV MMI $-120 \mathrm{~g} / \mathrm{m}^{2}$, LV relative wall thickness - 0.45, EDD $\mathrm{LV}-5.05 \mathrm{~cm}$ and the E/E' ratio -10.41 . Dilation of the LA was found in $33.3 \%(3 / 10)$ of the speed athletes. No athlete with EDD LV more than $6 \mathrm{~cm}$ was identified. That is, the speed performance training did not affect the structural and geometric reconstruction of the heart. Only one of the three athletes had moderate dilation of the LA, and one of the ten - LV concentric hypertrophy.

\section{Conclusions}

1. Despite long-term physical activity, normal LV geometry remained in $90 \%(9 / 10)$ of the speed athletes, in $74.2 \%(23 / 31)$ of the strength athletes and in $46.0 \%(29 / 63)$ of the endurance athletes $(P=0.012)$.

2. LV hypertrophy occurred more often (47.6 \% vs. $25.8 \%, P=0.044)$ in the endurance athletes as compared to the strength athletes.
3. Eccentric hypertrophy significantly prevailed over concentric type in the structure of hypertrophy in both the endurance athletes ( $34.9 \%$ vs. $12.7 \%, P=0.045$, respectively) and strength athletes (22.6\% vs. $3.2 \%$, $P=0.023$, respectively).

4. The largest left atrial diameter was registered in the endurance athletes, the smallest - in the strength athletes $(P=0.019)$.

Conflict of interest: authors have no conflict of interest to declare. Конфлікт інтересів: віАсутній.

Надійшла Ао редакції / Received: 27.04.2020

Після Аоопрацювання / Revised: 03.06.2020

Прийнято Ао Аруку / Accepted: 08.06.2020

Information about authors:

Malakhova S. M., MD, PhD, Associate Professor of

the Department of Physical Rehabilitation, Sports Medicine,

Physical Education and Health, Zaporizhzhia State Medical

University, Ukraine.

ORCID ID: 0000-0002-8197-299X

Syvolap V. V., MD, PhD, DSc, Professor, Head of the Department of Propedeutic Internal Medicine, Radiation Diagnostic and Radiation Therapy, Zaporizhzhia State Medical University, Ukraine. ORCID ID: 0000-0001-9865-4325

Potapenko M. S., MD, PhD, Assistant of the Department of Anesthesiology and Intensive Care, Zaporizhzhia State Medical University, Ukraine.

\section{Відомості про авторів:}

Малахова С. М., канА. меА. наук, Аоцент каф. фізичної реабілітації, спортивної меАицини, фізичного виховання і зАоров'я, Запорізький Аержавний медичний університет, Україна.

Сиволап В. В., А-р меА. наук, професор, зав. каф. пропедевтики внутрішньої медицини, променевої діагностики та променевої терапії, Запорізький Аержавний медичний університет, Україна. Потапенко М. С., канА. меА. наук, асистент каф. анестезіології та інтенсивної терапії, Запорізький Аержавний медичний університет, Україна.

\section{Сведения об авторах:}

Малахова С. Н., канА. меА. наук, Аоцент каф. физической реабилитации, спортивной меАицины, физического воспитания и зАоровья, Запорожский госуАарственный меАицинский университет, Украина.

Сыволап В. В, А-р меА. наук, профессор, зав. каф. пропедевтики внутренней медицины, пучевой Аиагностики и мучевой терапии, Запорожский государственный меАицинский университет, Украина.

Потапенко М. С., канА. меА. наук, ассистент

каф. анестезиологии и интенсивной терапии, Запорожский государственный медицинский университет, Украина.

\section{References}

[1] Ageev, F. T., \& Ovchinnikov, A. G. (2002). Diastolicheskaya disfunktsiya kak proyavlenie remodelirovaniya serdtsa [Diastolic dysfunction as the manifestation of cardiac remodeling]. Zhurnal serdechnaya nedostatochnost', 3(4), 190-195. [in Russian].

[2] Gavrilova, E. A., \& Zagorodnyi, G. M. (2019). Remodelirovanie serdtsa sportsmena $v$ zavisimosti ot napravlennosti trenirovochnogo protsessa [Remodeling of an athlete's heart, depending on the orientation of the training process]. Prikladnaya sportivnaya nauka, (1), 48-57. [in Russian].

[3] Kalyuzhin, V. V., Teplyakov, A. T., Solovtsov, M. A., Kalyuzhina, E. V., Bespalova, I. D., \& Terentyeva, N. N. (2016). Remodelirovanie levogo zheludochka: odin ili neskol'ko stsenariev? [Remodeling of the left ventricle: one or several scenarios?] Byulleten' sibirskoi meditsiny, 15(4), 120-139. https://doi.org/10.20538/1682-0363-2016-4-120-139 [in Russian]. 
[4] Komar, E. B., Morozov, V. N., \& Kalinkin, L. A. (2017). Osobennosti adaptatsii serdtsa legkoatletov vysokoi kvalifikatsii $k$ nagruzkam razlichnoi napravlennosti [The adaptation of high qualification athletes heart to different directions loads]. Vestnik sportivnoi nauki, (3), 32-35. [in Russian].

[5] Naumenko, E. P., Shilova, V. A., Semenyago, E. F., \& Korzheva, S. N. (2014). Vozmozhnosti sovremennoi tkanevoi dopplerografii v diagnostike narushenii strukturno - funktsional'nogo sostoyaniya miokarda u patsientov s ishemicheskoi bolezn'yu serdtsa i sakharnym diabetom 2 tipa [Possibilities of contemporary tissue doppler imaging in the diagnosis of structural and functional disorders of the myocardium in patients with coronary heart disease and type 2 diabetes mellitus]. GU «RNPTs RMiECh». [in Russian].

[6] Smolensky, A. V., Mikhailova, A. V., \& Tatarinova, A. Yu. (2017). Arterial'naya gipertoniya u sportsmenov i remodelirovanie sportivnogo serdtsa [Arterial hypertension and heart remodeling in athletes]. Mezhdunarodnyi zhurnal serdtsa i sosudistykh zabolevanii, 5(14), 36-45. [in Russian]

[7] Smolensky, A. V. (2018). Remodelirovanie sportivnogo serdtsa u sportsmenov s arterial'noi gipertoniei [Athletic heart remodeling in athletes with arterial hypertension]. Fiziologiya cheloveka, 44(1), 30-38. https:/l doi.org/10.7868/S0131164618010046 [in Russian].

[8] Ronzhina, O. A., \& Fomina, N. V. (2012). Remodelirovanie serdtsa i fizicheskaya rabotosposobnost' sportsmenov [Cardiac remodeling and athlets efficiency]. Meditsina v Kuzbasse, 11(2), 14-17. [in Russian].

[9] Sharykin, A. S., Badtieva, V. A., Trunina, I. I., \& Osmanov, I. M. (2019). Fibroz miokarda-novyi komponent remodelirovaniya serdtsa u sportsmenov? [Myocardial fibrosis - a new component of heart remodeling in athletes?]. Kardiovaskulyarnaya terapiya i profilaktika, 18(6), 126-135. https://doi.org/10.15829/1728-8800-2019-6-126-135 [in Russian]

[10] Cacciapuoti, F. (2011). Molecular mechanisms of left ventricular hypertrophy (LVH) in systemic hypertension ( $\mathrm{SH}$-possible therapeutic perspectives. Journal of the American Society of Hypertension, 5(6), 449-455. https://doi.org/10.1016/j.jash.2011.08.006

[11] Camici, P. G., Olivotto, I., \& Rimoldi, O. E. (2012). The coronary circulation and blood flow in left ventricular hypertrophy. Journal of Molecular and Cellular Cardiology, 52(4), 857-864. https://doi.org/10.1016/j. yimcc.2011.08.028

[12] Carbone, A., \& D'Andrea, A. (2017). Cardiac dysfunction and athlete's heart: new insights into pathophysiology and treatment. E-Journal of Cardiology Practice, 14(36), 23-27.

[13] Cocker, M. S., Strohm, O., Smith, D. J., Butler, C., Belenkie, I., Meeuwisse, W., \& Friedrich, M. G. (2008). Abstract 4194: Increased Incidence of Myocardial Fibrosis with Reduced Cardiac Function in Elite High-Endurance Athletes: A Cardiovascular Magnetic Resonance (CMR) Study. Circulation, 118(Suppl. 18), Article S 840.

[14] Eijsvogels, T., Oxborough, D. L., O'Hanlon, R., Sharma, S., Prasad, S., Whyte, G., George, K. P., \& Wilson, M. G. (2017). Global and regional cardiac function in lifelong endurance athletes with and without myocardial fibrosis. European Journal of Sport Science, 17(10), 1297-1303. https://doi.org/10.1080/17461391.2017.1373864

[15] Elliott, A. D., Mahajan, R., Linz, D., Stokes, M., Verdicchio, C. V., Middeldorp, M. E., La Gerche, A., Lau, D. H., \& Sanders, P. (2018). Atrial remodeling and ectopic burden in recreational athletes: Implications for risk of atrial fibrillation. Clinical Cardiology, 41(6), 843-848. https:// doi.org/10.1002/clc. 22967

[16] Emery, M. S., \& Kovacs, R. J. (2018). Sudden Cardiac Death in Athletes. JACC: Heart Failure, 6(1), 30-40. https://doi.org/10.1016/j. jchf.2017.07.014

[17] Frey, N., Katus, H. A., Olson, E. N., \& Hill, J. A. (2004). Hypertrophy of the heart: a new therapeutic target? Circulation, 109(13), 1580-1589. https://doi.org/10.1161/01.CIR.0000120390.68287.BB

[18] La Gerche, A., Burns, A. T., Mooney, D. J., Inder, W. J., Taylor, A. J., Bogaert, J., Macisaac, A. I., Heidbüchel, H., \& Prior, D. L. (2012). Exercise-induced right ventricular dysfunction and structural remodelling in endurance athletes. European Heart Journal, 33(8), 998-1006. https:// doi.org/10.1093/eurheart//ehr397

[19] Lang, R. M., Badano, L. P., Mor-Avi, V., Afilalo, J., Armstrong, A. Ernande, L., Flachskampf, F. A., Foster, E., Goldstein, S. A., Kuznetsova, T., Lancellotti, P., Muraru, D., Picard, M. H., Rietzschel, E. R., Rudski, L., Spencer, K. T., Tsang, W., \& Voigt, J. U. (2015). Recommendations for cardiac chamber quantification by echocardiography in adults: an update from the American Society of Echocardiography and the European Association of Cardiovascular Imaging. European Heart Journal Cardiovascular Imaging, 16(3), 233-271. https://doi. org/10.1093/ehjci/jev014

[20] Lazzeroni, D., Rimoldi, O., \& Camici, P. G. (2016). From Left Ventricular Hypertrophy to Dysfunction and Failure. Circulation Journal, 80(3), 555-564. https://doi.org/10.1253/circj.CJ-16-0062

[21] Limongelli, G., Rea, A., Masarone, D., Francalanci, M. P., Anastasakis, A., Calabro', R., Giovanna, R. M., Bossone, E., Elliott, P. M., \& Pacileo, G. (2015). Right ventricular cardiomyopathies: a multi- disciplinary approach to diagnosis. Echocardiography, 32(Suppl. 1), S75-S94. https://doi.org/10.1111/echo.12399

[22] Lippi, G., Cervellin, G., Banfi, G., \& Plebani, M. (2011). Cardiac troponins and physical exercise. It's time to make a point. Biochemia Medica, 21(1), 55-62. https://doi.org/10.11613/bm.2011.012

[23] Lovic, D., Erdine, S., \& Catakoğlu, A. B. (2014). How to estimate left ventricular hypertrophy in hypertensive patients. Anadolu Kardiyoloji Dergisi, 14(4), 389-395. https://doi.org/10.5152/akd.2014.5115

[24] Nagueh, S. F., Smiseth, O. A., Appleton, C. P., Byrd, B. F., 3rd, Dokainish, H., Edvardsen, T., Flachskampf, F. A., Gillebert, T. C., Klein, A. L. Lancellotti, P., Marino, P., Oh, J. K., Popescu, B. A., \& Waggoner, A. D. (2016). Recommendations for the Evaluation of Left Ventricular Diastolic Function by Echocardiography: An Update from the American Society of Echocardiography and the European Association of Cardiovascular Imaging. Journal of the American Society of Echocardiography, 29(4), 277-314. https://doi.org/10.1016/i.echo.2016.01.011

[25] Ponikowski, P., Voors, A. A., Anker, S. D., Bueno, H., Cleland, J. Coats, A., Falk, V., González-Juanatey, J. R., Harjola, V. P., Jankowska, E. A., Jessup, M., Linde, C., Nihoyannopoulos, P., Parissis, J. T., Pieske, B., Riley, J. P., Rosano, G., Ruilope, L. M., Ruschitzka, F., Rutten, F. H., ... ESC Scientific Document Group. (2016). 2016 ESC Guidelines for the diagnosis and treatment of acute and chronic heart failure: The Task Force for the diagnosis and treatment of acute and chronic heart failure of the European Society of Cardiology (ESC) Developed with the special contribution of the Heart Failure Association (HFA) of the ESC. European Heart Journal, 37(27), 2129-2200. https:// doi.org/10.1093/eurheartj/ehw128

[26] Richardson, A. J., Leckie, T., Watkins, E. R., Fitzpatrick, D., Galloway, R., Grimaldi, R., \& Baker, P. (2018). Post marathon cardiac troponin $T$ is associated with relative exercise intensity. Journal of Science and Medicine in Sport, 21(9), 880-884. https://doi.org/10.1016/j. jsams.2018.02.005

[27] Trivax, J. E., \& McCullough, P. A. (2012). Phidippides Cardiomyopathy: AReview and Case lllustration. Clinical cardiology, 35(2), 69-73. https:// doi.org/10.1002/clc.20994

[28] Wilson, M. G., Drezner, J. A., \& Sharma, S. (Eds.). (2016). IOC Manual of Sports Cardiology. John Wiley \& Sons, Ltd. https://doi. org/10.1002/9781119046899

[29] Żebrowska, A., Waśkiewicz, Z, Nikolaidis, P. T., Mikołajczyk, R. Kawecki, D., Rosemann, T., \& Knechtle, B. (2019). Acute Responses of Novel Cardiac Biomarkers to a 24-h Ultra-Marathon. Journal of Clinical Medicine, 8(1), Article 57. https://doi.org/10.3390/jcm8010057 